\title{
The Triticeae (Gramineae) in Australasia
}

\author{
Mary E. Barkworth ${ }^{1}$ and Surrey W.L. Jacobs ${ }^{2+}$ \\ ${ }^{1}$ Intermountain Herbarium, Utah State University, Logan, Utah 84322-5305. \\ ${ }^{2}$ National Herbarium, Royal Botanic Gardens, Sydney, New South Wales 2000, Australia \\ Author for correspondence: mary@biology.usu.edu
}

\begin{abstract}
We endorse recognition of four morphologically and cytologically distinct genera for Australasia's native Triticeae: Australopyrum, Stenostachys, Anthosachne and Connorochloa. To encourage adoption of this recommendation, we present a key to all genera of Triticeae found in Australasia, descriptions of the native genera, keys to their species, the new combinations required to implement our generic recommendations (Anthosachne falcis, A. fertilis, A. longiseta, A. multiflora var. kingiana, A. plurinervis, A. rectiseta, A. solandri and Stenostachys enysii), and representative line drawings. These and additional identification resources are available on the web at http://herbarium.usu.edu/triticeae. We also lectotypify Agropyron velutinum Nees.
\end{abstract}

\section{Introduction}

Löve (1984) and Dewey (1984) independently proposed using genomic constitution to determine generic boundaries in the Triticeae, species with different genomic constitutions being placed in different genera. They argued that these genomic genera would better reflect phylogenetic relationships within the tribe; Dewey added that they would be a better guide for plant breeders. By genomic analysis, Löve and Dewey referred to analysis of pairing behaviour of the chromosomes in hybrid plants, hybrids in which there was complete, or almost complete, pairing at metaphase being interpreted as having the same genomes. The response from taxonomists was largely negative (see, e.g., Baum et al. 1987, Kellogg 1989, Seberg \& Peterson 1998). Most objected on theoretical grounds, but many field-oriented scientists objected that the genomic genera could not be identified morphologically, a factor that limited their utility.

Löve (1984) listed the genomic constitution of all the taxa he recognised but, as he stated in his introduction, he was often forced to infer the information from existing taxonomic treatments, not cytogenetic analysis. In the last 25 years, cytological and molecular information about the Triticeae has increased significantly, resulting in the discovery of more haplomes, and combinations of haplomes, than was known in 1984, particularly within Elymus sensu Löve and Dewey (see http://herbarium.usu.edu/

${ }^{\dagger}$ Deceased November 262009. 
Triticeae/genomes.htm). These studies have also consistently demonstrated a strong correlation between the cytogenetic and molecular information, a correlation so strong that molecular information is often used nowadays to infer genomic constitution (e.g., Stewart et al 2005, Liu et al. 2008). Of particular importance to this paper, all Australasian taxa have been shown to contain the $\mathbf{W}$ genome, either by itself, as in Australopyrum, or in one of three different combinations: HW, StYW, and StYHW (genome symbols from the International Triticeae Consortium; http://herbarium.usu. edu/Triticeae/genmsymb.htm) which correspond to the genomic genera Stenostachys, Anthosachne, and Connorochloa, respectively.

There have been few formal investigations of the relationship between morphology and genomic constitution in the perennial Triticeae. Salomon and Lu (1992) studied seven taxa in two genomic groups, $\mathbf{S t Y}$ and $\mathbf{S t H}$, and found a correlation between genome constitution and palea apex shape and the size and abundance of the teeth on the palea keels. Baum et al. (1995) conducted discriminant analysis of nine characters scored on 290 specimens representing 100 species in four genomic groups, P, StH, StYP, and StY. The resulting functions correctly identified the genomic group of the specimens $73 \%$ of the time. Barkworth et al. (2009) used Random Forests analysis (Cutler et al. 2007) of data for 61 morphological characters scored on 218 specimens representing 13 different genomic groups. The analysis correctly identified the genomic group of $87 \%$ of the specimens among which were all but one of the Australasian specimens (an StYHW specimen that was identified as StYW). Moreover, when asked to classify specimens as to whether they had or did not have the $\mathbf{W}$ genome (which corresponds to Australasian or non-Australasian), Random Forests Analysis achieved a 95\% success rate for the $\mathbf{W}$-containing specimens and $97 \%$ success rate for the others. Given these high success rates for morphological identification of the genomic constitution of Australasian specimens, we support recognition of four genera within Australasia's native Triticeae: Australopyrum, Stenostachys, Anthosachne, and Connorochloa. Their genomic constitutions are W, HW, StYW, and StYHW respectively. The purpose of this paper is to provide the names required for implementation of this recommendation and descriptions and keys for the genera and species involved. Descriptions of the species can be found in Hitchcock (1936), Veldkamp and van Scheindelen (1989) Edgar and Connor (2000), Jacobs et al. (2009), Flora of Australia (2009), and online at http://herbarium.usu.edu/Triticeae.

\section{Materials and methods}

We developed comparable descriptions for all the Australasian taxa based on examination of specimens in CANB, CHR, MEL, NSW, UNE, and UTC and from published descriptions (Hitchcock 1936, Veldkamp \& van Scheindelen 1989, Edgar \& Connor 2000, Jacobs et al. 2008, Flora of Australia 2009). In doing so, we followed a standard format, appropriate for incorporation into Fact Sheet Fusion (CBIT 2005), a program that facilitates development of interlinked web pages.

We used the information in the descriptions to develop dichotomous and/or multiaccess keys for identification of all genera of the Triticeae that have been found in Australasia and the species of each Australasian genus. To create the generic key, we drew on descriptions of the genera at http://herbarium.usu.edu/Triticeae. The programs used to generate the keys were Phoenix (CBIT 2004) and Lucid 3.5 (CBIT 2009). 


\section{Results}

It was clear from our examination of specimens, particularly those of Anthosachne, that there is need for a revisionary treatment of the Triticeae in Australasia, a task that was beyond the scope of this project. Nevertheless, we decided that it would be useful to provide a treatment that is based on existing treatments (Edgar \& Connor 2000, Jacobs et al. 2008, Flora of Australia 2009) at the species level but reflects our generic conclusions. We present first a key to the genera found in Australasia followed by brief descriptions of the native genera and line drawings of representative species. Each generic description is followed by a key to its species and a listing of those recognised. The new combinations are presented in the species listings. The species listings end with information on the location of type specimens but we have only examined types followed by an exclamation point (!) or, if the exclamation point follows the word "image", only an image of the specimen. Additional illustrations are available at http://herbarium.usu.edu/Triticeae/Australasia.

\section{Key to the genera of Triticeae in Australasia}

1. Inflorescences with 3 spikelets per node, each spikelet with 1 floret, usually only the floret of the central spikelet seed-forming (all florets seed-forming in most cultivated plants); disarticulation in the rachis (cultivated species not disarticulating)

Hordeum

1'. Inflorescences with 1-5 spikelets per node, usually all spikelets with 2 or more florets, sometimes only the lowest floret in each spikelet seed-forming, sometimes all spikelets in the upper nodes sterile; disarticulation usually below the florets or the florets, sometimes in the rachis (cultivated species not disarticulating) 2

2. Plants annual; inflorescence erect at anthesis and often remaining so afterwards.......... 3

3. Glumes $2-5 \mathrm{~mm}$ wide, the tips truncate or toothed Triticum

3. Glumes $0.5-2 \mathrm{~mm}$ wide, awnlike at the tips or throughout 4

4. Lemmas evidently keeled, the keels rigidly pectinate-ciliate; lemma awns remaining straight at maturity; all spikelets with at least one seed-forming floret Secale

4. Lemmas not keeled, the midveins scabrous; lemma awns bent at maturity; distal spikelets sterile

Taeniatherum

2. Plants perennial; inflorescence drooping or erect at anthesis

5. Plants usually strongly rhizomatous, sometimes not rhizomatous; lemmas unawned or with an awn no more than $4 \mathrm{~mm}$ long; inflorescences erect or nodding at maturity, the spikelets appressed or strongly ascending

6. Inflorescence with $2-5$ spikelets per node

Leymus

6. Inflorescence with 1 spikelet per node

7. Adaxial surface of the blades with inconspicuous, widely spaced ribs; glumes lanceolate; lemmas mucronate or awned

Elymus

7. Adaxial surface of the blades with prominent, closely spaced ribs; glumes lanceolate-oblong to rectangular; lemmas truncate, obtuse, or mucronate Thinopyrum

5. Plants not or only weakly rhizomatous; lemmas often with awns longer than 6 $\mathrm{mm}$ but sometimes all lemmas only shortly awned; inflorescences often drooping or arcuate at maturity, sometimes erect to nodding, the spikelets often strongly divergent to reflexed, sometimes appressed to strongly ascending. 
8. Spikelets 10-15 mm long; lemma awns to $5 \mathrm{~mm}$ long ......................................... 9

9. Spikelets sessile, appressed rachis; rachis surfaces glabrous; glumes usually absent or strongly reduced, sometimes to $9 \mathrm{~mm}$ long and 1-3-veined; lemmas often minutely bifid at the base of the awn Stenostachys

9'. Spikelets on pedicels about $1 \mathrm{~mm}$ long, often strongly divergent to reflexed; rachis surfaces usually hairy; glumes usually well-developed, 1.3-8 mm long 1-5-veined; lemmas not bifid Australopyrum

8'. Spikelets $15-100 \mathrm{~mm}$ long; lemmas usually awned, longest awns $4.4-75 \mathrm{~mm}$

long, sometimes lemmas unawned 10

10. Peduncles not or scarcely elongating after anthesis; basal leaf blades 1-7 $\mathrm{mm}$ wide or involute and $0.5-0.7 \mathrm{~mm}$ in diameter Anthosachne

10 ' Peduncles strongly elongating after anthesis; basal leaf blades 1-2 mm wide Connorochloa

\section{Australopyrum (Tzvelev) Á.Löve}

Australopyrum (Tzvelev) Á.Löve, Feddes Repert. 95(7-8): 442 (1984). Basionym: Agropyron sect. Australopyrum Tzvelev, Novosti Sist. Vyssh. Rast. 10: 35 (1973). Type: Australopyrum pectinatum (Labill.) Á.Löve. Fig. 1.

Plants perennial, loosely tufted. Culms $10-70 \mathrm{~cm}$ tall; lowest internode $0.5-2.2 \mathrm{~mm}$ thick. Leaf blades $0.5-3.5 \mathrm{~mm}$ wide, flat to loosely involute. Inflorescence spikelike, $1.5-13 \mathrm{~cm}$ long; rachis tough, usually prolonged beyond the base of the distal spikelet up to $3.5 \mathrm{~mm}$; lowest internode 3-12 mm long; middle internodes $2-7 \mathrm{~mm}$ long; disarticulation below the glumes. Spikelets solitary, tangential to the rachis, 7.5-19 mm long, with 3-9 florets, not pedicellate or on pedicels to $1 \mathrm{~mm}$ long, tangential to and usually strongly divergent or reflexed from the rachis, sometimes ascending. Glumes 5-9 mm long, stiff, narrowly lanceolate, to awnlike. Lemmas 4.8-11 mm long, awned, awns to $4 \mathrm{~mm}$, straight. Paleas from $3 / 4$ as long as to equalling the lemmas, keel veins with widely spaced long, coarse teeth, often extending beyond the intercostal region, converging to a narrow tip, the keel veins often extending beyond the intercostal region. Anthers 1-6 $\mathrm{mm}$ long.

Distribution: one species native to Papua New Guinea, three to Australia, and one to New Zealand.

Cytology: $2 n=14$, determined on A. velutinum (Löve et al. 1982), A. calcis, A.pectinatum, and $A$. retrofractum (Connor et al. 1993). Genomic constitution: W. Löve assigned the letter, assuming that the haplome of Austalopyrum differed from that of other diploids in the tribe. Subsequent work has supported his interpretation (Torabinejad \& Mueller 1993, Stewart et al. 2005, Liu et al. 2006).

History: Australopyrum was first recognised by Tzvelev (1973) as a section of Agropyron, differing from sect. Agropyron in its pedicellate, strongly divergent spikelets. Löve (1984) raised it to generic status, including in it the diploid Triticeae from Australia and New Zealand. The genus has been accepted in subsequent works by Australian and New Zealand botanists (Wheeler et al. 1990, 2002; Connor 1993; Edgar \& Connor 2000; Jacobs et al. 2008; Henwood \& Weiller 2009). 


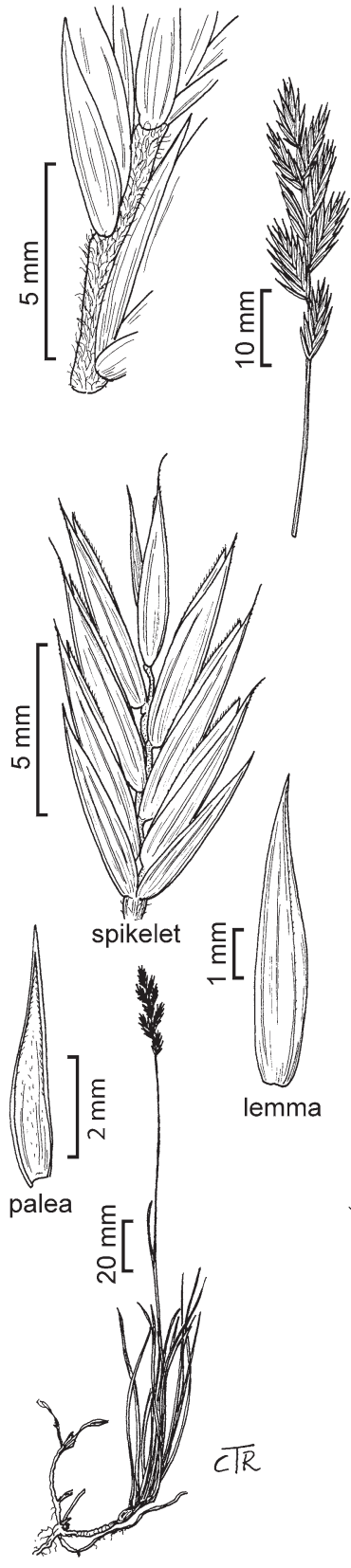

A. velutinum

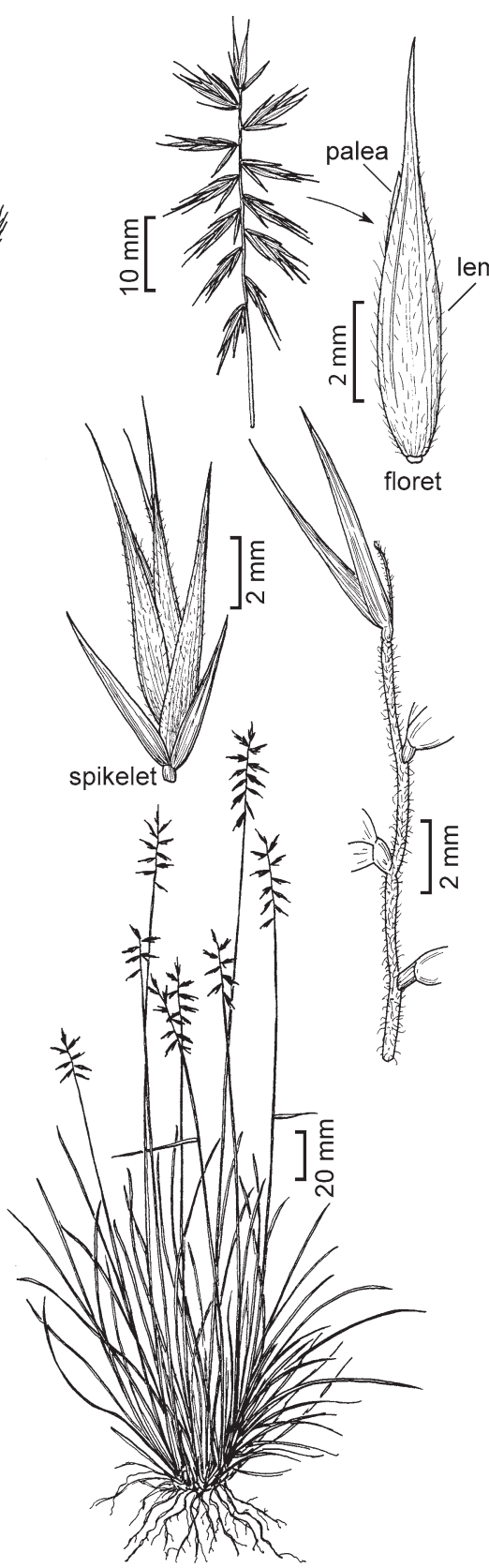

A. pectinatum

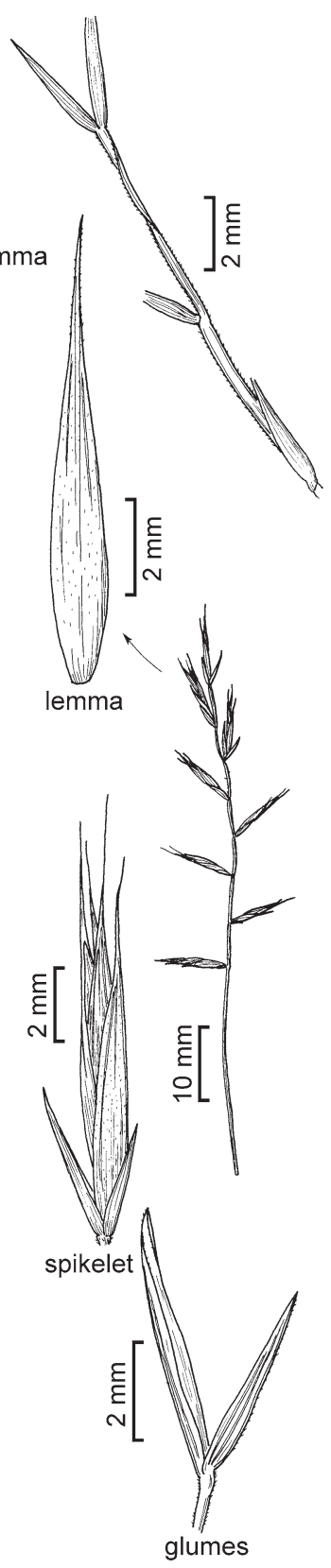

A. calcis

Fig. 1. Representative species of Australopyrum. Australopyrum velutinum: Phillips 108056, CBG10856[sic]; A. pectinatum: Pullen 11077, CANB345595; Agropyron calcis ssp. calcis: Molloy \& Ryan L4, CHR468519. Isolated florets and lemmas are from the lowest floret in a spikelet. 
1. Tips of the lemmas, and sometimes the glumes, bent downwards forming an uncinate hook......

1. Tips of the lemmas and glumes straight, not forming a hook 2

2. Glumes remaining appressed to the lemmas; spikelets ascending at maturity, almost concealing the rachis

A. velutinum

2'. Glumes strongly divergent at maturity; spikelets spreading to reflexed at maturity, exposing the rachis...... 3

3. Rachis internodes and nodes retrorsely or strongly divergently hairy

3'. Rachis internodes antrorsely hairy or glabrous, nodes sometimes retrorsely hairy 4 4. Leaves coarsely hairy on the lower surface; lemma tip smooth, shining

A. pectinatum

4. Leaves glabrous on the lower surface; lemma tip scabrous, dull A. calcis

Australopyrum calcis Connor \& Molloy, New Zealand J. Bot. 31: 2 (1993). Type: New Zealand, Marlborough, Leatham River, near limestone quarry; 600 m; B.P.J. Molloy \& K.W. Ryan L2; 29 January 1991 (holotype: CHR468517a).

Australopyrum calcis Connor \& Molloy subsp. calcis. Nomenclatural synonym: Australopyrum pectinatum var. calcis (Connor \& Molloy) C.Yen \& J.L.Yang, Xiao mai zu sheng wu xi tong xue 3: 189 (2006).

NEW ZEALAND: South Island, Marlborough.

Australopyrum calcis subsp. optatum Connor \& Molloy, New Zealand J. Bot. 31:4 (1993). Nomenclatural synonym: Australopyrum pectinatum var. optatum (Connor \& Molloy) C.Yen \& J.L.Yang, Xiao mai zu sheng wu xi tong xue 3: 190 (2006). Type: New Zealand, Canterbury, Flock Hill, above cave, cave stream, 780 m, B.P.J. Molloy FH 1a, 1 Jan 1991 (holotype: CHR468526a).

NEW ZEALAND: South Island, North Canterbury.

Australopyrum pectinatum (Labill.) Á.Löve. Basionym: Festuca pectinata Labill., Nov. Holl. Pl. 1: 21, t. 25 (1805). Nomenclatural synonym: Agropyron pectinatum (Labill.) P. Beauv., Ess. Agrostogr. 102, 146, 180 (1812). Type: Australia, Tasmania, "Habitat in capite Van-Diemen [Hobart]"; Labilliardière s.n. (holotype: FI, n. 205302 Herb. Webbianum, image!; isotype: NY381153, image!)

AUSTRALIA: Queensland, New South Wales, Victoria, Tasmania.

NEW ZEALAND: Naturalised on North Island (Hawkes Bay) and South Island (Central Otago).

Australopyrum retrofractum (Vickery) Á.Löve, Feddes Repert. 95: 443 (1984). Basionym: Agropyron retrofractum Vickery, Contr. New South Wales Natl. Herb. 1(6): 340-341 (1951). Nomenclatural synonyms: Australopyrum pectinatum subsp. retrofractum (Vickery) Á.Löve, Taxon 32: 86 (1983); Australopyrum pectinatum var. retrofractum (Vickery) C.Yen \& J.L.Yang, Xiao mai zu sheng wu xi tong xue 3: 190 (2006). Type: Australia, New South Wales, Rock Flat near Cooma, E. Betche s.n., Feb 1893 (holotype: NSW 9116).

AUSTRALIA: New South Wales, Victoria.

NEW ZEALAND: Naturalised on North Island. 
Australopyrum uncinatum Veldkamp, Blumea 34(1): 67, f. 1a (1989). Type: Papua New Guinea, Northern District, subdistrict Kokoda, Mt. Kenive (Nisbet), 3000 m, J.R. Croftetal. LAE65112, 30 Jul 1974 (holotype:L233077; isotypes:A, BRI, CANB391072!, K, L233076, LAE216269).

PAPUA NEW GUINEA: Northern Province.

Australopyrum velutinum (Nees) B.K.Simon, Austrobaileya 2: 241 (1986). Basionym: Agropyron velutinum Nees, London J. Bot. 2: 417 (1843). Nomenclatural synonyms: Australopyrum retrofractum subsp. velutinum (Nees) Á.Löve, Feddes Repert. 95: 443 (1984); Australopyrum pectinatum var. velutinum (Nees) C.Yen \& J.L.Yang, Xiao mai zu sheng wu xi tong xue 3: 191 (2006). Type: Australia, Insulae Van Diemen [Tasmania], in Chilton, Surrey Hills, Gunn 770, Feb 1837 (lectotype (designated here): K, image! at http://apps.kew.org/herbcat/navigator.do; isolectotype: CGE, Lindley Herbarium, image! at http://www.tropicos.org).

AUSTRALIA: New South Wales, Victoria, Tasmania.

\section{Stenostachys Turcz.}

Stenostachys Turcz., Bull. Soc. Imp. Naturalistes Moscou 35(2): 330 (1862). Type: Stenostachys narduroides Turcz. [= Stenostachys gracilis (Hook.f.) Connor]. Fig. 2.

Plants perennial, stoloniferous. Culms $29-80 \mathrm{~cm}$ tall, lowest internode $0.6-1.5 \mathrm{~mm}$ thick. Leaf blades 1-4 mm wide, flat, adaxial surface usually with moderately prominent ribs. Inflorescence spikelike, nodding or drooping; rachis tough, surfaces glabrous, prolonged for (0.2)0.5-6 mm beyond the base of the most distal spikelet, middle internodes 2-7 mm long; initial disarticulation below the florets, glumes following soon thereafter. Spikelets solitary, not pedicellate, appressed to divergent, lowest spikelet slightly longer than the adjacent internode, middle spikelets from 2-3 times longer than the adjacent internode. Glumes absent or to $6.7 \mathrm{~mm}$ long, shorter than the adjacent lemma, to $0.9 \mathrm{~mm}$ wide, tangential to the rachis, subulate to lanceolate but tapering from near midlength to an awnlike tip, membranous with a scarious margin when not subulate, usually scabridulous. Florets radial or almost radial to the rachis; rachilla glabrous on the surfaces. Lemmas usually mostly smooth but scabrous distally, at least over the midvein, sometimes scabrous throughout, rounded over most of the midvein but keeled distally, tips often bidentate, midvein extending into an awn 0.5-6.5 $\mathrm{mm}$ long. Paleas tapering in the distal quarter. Lodicules lobed or entire, sometimes ciliate distally. Anthers 1.5-3 mm long.

Distribution: four species, all native to New Zealand.

Cytology: $2 \mathrm{n}=28$, counted on S. enysii, S. gracilis, and S. laevis (Hair in Connor 1954). Genomic constitution HW, demonstrated for S. enysii by Svitashev et al. (1998) and for all four species by Stewart et al. (2005). $\mathbf{H}$ is the maternal genome.

History: Stenostachys was established by Turczaninow (1862) with S. narduroides $[=$ S. gracilis $]$ as the type. Löve and Connor (1982) treated it as Elymus sect. Stenostachys (Turcz.) Á.Löve \& Connor but in 1994 Connor argued for its reinstatement as a genus, with Cockaynea Zotov as a synonym, on the basis of its distinct morphology. Our interpretation of Stenostachys differs from that of Connor $(1994,2005)$ and Edgar and Connor (2000) in the inclusion of S. enysii which Connor initially included in Elymus but later transferred to Australopyrum. It differs from the other species of Stenostachys 


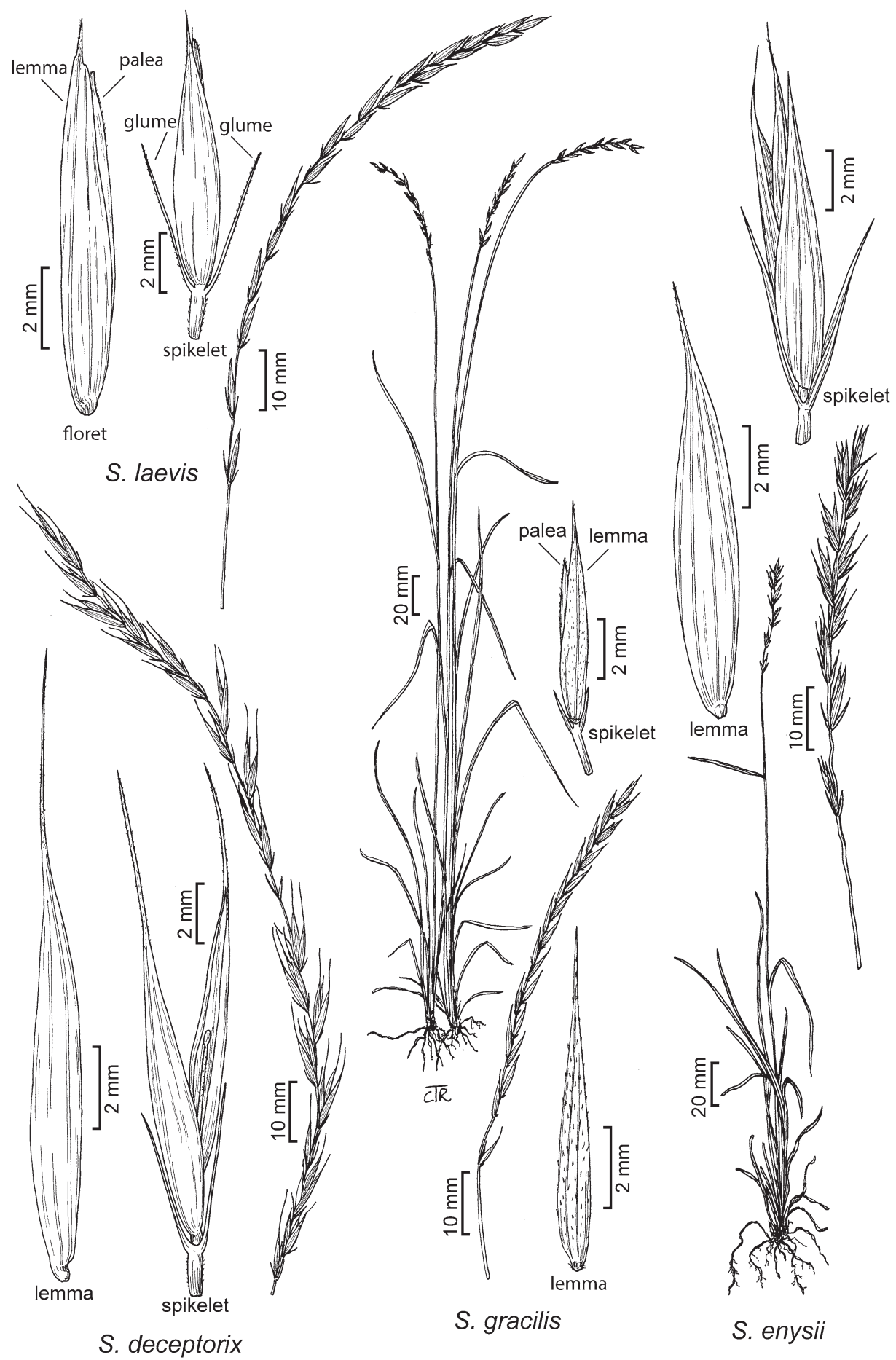

Fig. 2. Stenostachys. Stenostachys laevis: Wardle, 23 Feb 1972, CHR223892; S. deceptorix: Druce S46 85-04, CHR358102; S. gracilis: Talbot, Jan. 1949, CHR301426; S. enysii: Zotov, CHR225704. 
in its well developed glumes but its florets are radial to the rachis. It differs from most species of Australopyrum in having rachises with glabrous surfaces and rachis internodes that are longer relative to the spikelets.

1. Glumes 3-veined to about midlength; blades $2-4 \mathrm{~mm}$ wide S. enysii

1'. Glumes 1-veined their whole length; blades $1-2.5 \mathrm{~mm}$ wide. 2

2. Lemmas scabrous or stiffly hairy all over; at least some glumes absent or minute

S. gracilis

2'. Lemmas usually smooth except before the awns, occasionally sparsely scabrous elsewhere; 2-10 mm long..... 3

3. Lemmas mucronate or with awns to $2 \mathrm{~mm}$ long; glumes $2-6 \mathrm{~mm}$ long ....... S. laevis

3. Lemmas awned, awns 5-6.5 mm long; glumes 5-10 mm long. S. deceptorix

Stenostachys deceptorix Connor, New Zealand J. Bot. 32: 144 (1994). Type: New Zealand, Stone Creek, S.W. Mt Luna, 3800', A.P. Druce s.n, Jan 1971 (holotype: CHR249929). NEW ZEALAND: South Island.

Stenostachys enysii (Kirk) Barkworth \& S.W.L.Jacobs comb. nov. Basionym: Agropyron enysii Kirk, Trans. \& Proc. New Zealand Inst. 27: 352 (1895). Nomenclatural synonyms: Asprella aristata Petrie, Trans. \& Proc. New Zealand Inst. 26: 272 (1894), nom. illeg., non Asprella aristata Kuntze (1891); Agropyron aristatum Cheeseman, Illustrated Fl. New Zealand, ed. 2: 234 (1914), nom. superfl.; Agropyron aristatum Druce, Rep. Bot. Exch. Cl. Brit. Isles: 603 (1917), nom. superfl.; Elymus enysii (Kirk) Á.Löve \& Connor, New Zealand J. Bot. 20: 183 (1982); Australopyrum enysii (Kirk) Connor, New Zealand J. Bot. 43:504 (2005). Type: New Zealand, Mt Torlesse Canterbury Alps, c. 3600 ft, D. Petrie s.n., Jan 1893. (lectotype (Connor 1994): WELT68390, image!)

Stenostachys gracilis (Hook.f.) Connor, New Zealand J. Bot. 32: 146 (1994). Basionym: Gymnostichium gracile Hook.f., Fl. New Zealand 1: 312 (1853). Nomenclatural synonyms: Hystrix gracilis (Hook.f.) Kuntze, Revis. Gen. Pl. 2: 778 (1891); Asperella gracilis (Hook.f.) Kirk, Trans. \& Proc. New Zealand Inst. 27: 352 (1895); Cockaynea gracilis (Hook.f.) Zotov, Trans. \& Proc. Roy. Soc. New Zealand 73: 234 (1943). Type: New Zealand, woods at Patea Village, Colenso 1611. (lectotype (Connor 1994): K).

Taxonomic synonyms: Stenostachys narduroides Turcz., Bull. Soc. Imp. Naturalistes Moscou 35: 331 (1862); Elymus narduroides (Turcz.) Á.Löve \& Connor, New Zealand J. Bot. 20: 184 (1982). Type: New Zealand, J.E. Home s.n. (holotype: LE).

Agropyron subeglume P.Candargy, Etude Monogr. Hordees (Archiv. Biol. Veg., Athenes, Fasc. 1) 32, in clavi, 64 (1901). Type: New Zealand, Alaroa, Raoul 241, 1843. (holotype: K).

NEW ZEALAND: South Island.

Stenostachys laevis (Petrie) Connor, New Zealand J. Bot. 32: 146 (1994). Basionym: Asprella laevis Petrie, Trans. \& Proc. New Zealand Inst. 27: 406 (1895). Nomenclatural synonyms: Cockaynea laevis (Petrie) Zotov, Trans. \& Proc. Roy. Soc. New Zealand 73: 234 (1943); Hystrix laevis (Petrie) Allan, Bull. Dept. Sc. \& Indust. Res. N. Z. 49: 88 (1936); Elymus laevis (Petrie) Á.Löve \& Connor, New Zealand J. Bot. 20: 184 (1982), nom. illeg., non Elymus laevis (Scribn. \& J.G.Sm.) Hoover. Type: New Zealand, Matukituki Valley D. Petrie, Mar 1893. (lectotype (Connor 1994): WELT68353).

NEW ZEALAND: North Island. 


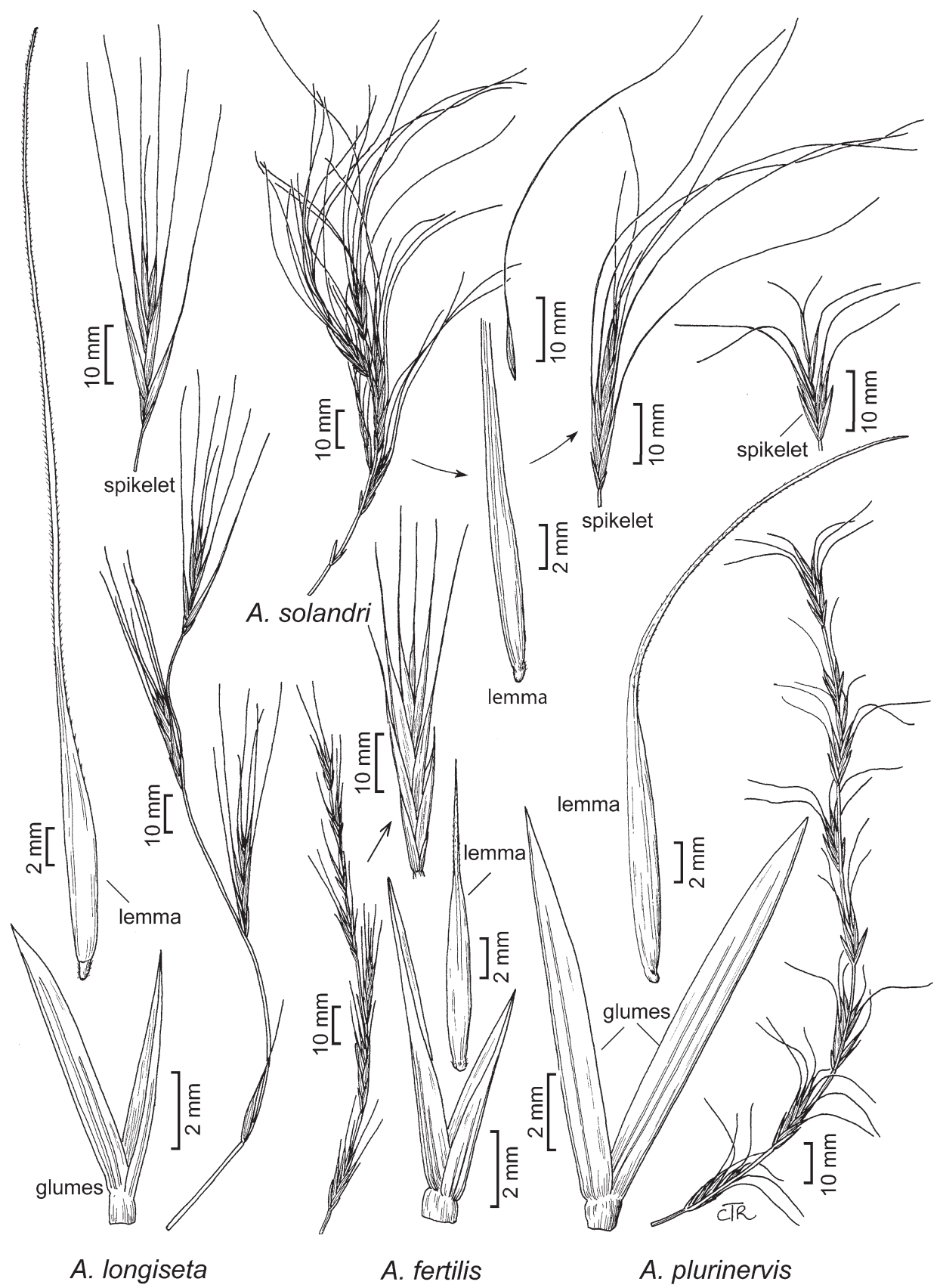

Fig. 3. ANTHOSACHNE

Fig. 3. Representative species of Anthosachne. Anthosachne fertilis: Pedley 713, CANB93628; A. longiseta: Robbins 2757, CANB87785; A. plurinervis: Bisset S. 752, CANB22846; A. solandri: Druce S35 93-42, CHR387018 Drawings of the isolated florets are of the lowest floret in a spikelet. 


\section{Anthosachne Steud.}

Anthosachne Steud., Syn. Pl. Glumac.1: 237 (1854). Type: Anthosachne australasica $[=$ A. rectiseta $]$. Fig. 3 .

Plants perennial, densely to loosely clumped, sometimes rhizomatous or stoloniferous. Culms 20-170 cm tall, erect, ascending, arcuate or prostrate; lowest internode 0.4-2.4 mm thick. Leaf blades 1-7 mm wide and flat to folded or involute and 0.5$0.7 \mathrm{~mm}$ in diameter. Inflorescences spike-like, 2-70 cm long, with (2)4-20 spikelets; rachis tough, terminating in a spikelet; lowest internode $8-55 \mathrm{~mm}$ long, longer than the middle internodes; middle internodes 7-36 mm long; disarticulation below the florets. Spikelets solitary, tangential to the rachis, $15-55 \mathrm{~mm}$ long, sessile or on pedicels up to $0.3 \mathrm{~mm}$ long, usually divergent, sometimes appressed. Glumes lanceolate, $1.3-13 \mathrm{~mm}$ long, subequal or the lower much shorter than the upper, acute, muticous or the midvein extended into a straight or recurved awn. Lemmas lanceolate, unawned or awned, awn to $75 \mathrm{~mm}$, straight to recurved. Palea from half as long as to subequal to the lemma, curved to the narrow tip, keels with coarse, well-spaced teeth, intercostal region bifid or retuse to truncate. Lodicules ciliate distally. Anthers 1.6-9 mm.

Distribution: Papua New Guinea, Australia, New Zealand.

Cytology: Torabinejad et al. (1987) showed that three of the Australian taxa were hexaploids and postulated that their genomic composition was StYW or HYW. Subsequently, Dawson (2000) and Murray et al. (2005) showed that the New Zealand species were all hexaploids. Redibaugh et al. (2000) demonstrated that Elymus rectisetus $[$ An. $\equiv$ rectiseta] was StYW and Stewart et al. (2005) showed that this was also the genomic constitution of the New Zealand hexaploids. There is no cytological information for Anthosachne longiseta.

History: Steudel (1854) was the first to recognise Anthosachne, creating it to accommodate one species, $A$. australasica [ $\equiv$ A. rectiseta]. Nevski (1934) expanded it to include A. scabra plus three Asian species. Melderis (1970) treated Anthosachne as a section of Agropyron and added more Asian species to it. Tsvelev (1973) transferred it, as a section, to Elymus, and added still more Asian species to it. Löve also treated Anthosachne as a section of Elymus but expanded it to include, in addition to several Asian species, seven Australasian species, including one tetraploid, three hexaploids, one octoploid, and two species for which there were no cytogenetic data. He assumed that all species of Elymus, including those of sect. Anthosachne, contained only the St and $\mathbf{H}$ genomes.

Since 1990, the Asian species placed in sect. Anthosachne have been shown to be StY tetraploids, differing in this respect from the Australasian taxa. Based on this information, Yen et al. (2006) returned Anthosachne to generic status and restricted it to Australasian hexaploids with the genomic constitution StYW, placing the Asian species in the genus Roegneria. Unfortunately, they did not provide all of the combinations needed and some of those they did make are invalid, are based on nomenclatural synonyms, or reflected a dated species classification without providing reasons for doing so.

Anthosachne differs from most genera of the Triticeae in its tendency to have rather slender culms with drooping inflorescences and large, widely spaced, solitary spikelets. The glumes are usually very short compared to the adjacent lemmas and narrow from near the base. It is also the only genus in the Triticeae in which apomixis is known to occur (Hair 1956, Murphy 2003, Connor 2005). We agree with Yen et al. that it should 
be restricted to Australasian hexaploids because they are morphologically, cytologically, and geographically distinct from other Triticeae.

Examination of specimens from AD, CHR, MEL, NSW, NE, and PERTH plus field work and discussions with Neville Walsh and Wal Whalley indicate that a detailed study of the genus is needed, one that includes examination of variation throughout Australia, a finding that echoes comments in Murphy and Jones (1999) and Murphy (2003). Until a more detailed study has been completed, it seems best to make minimal changes to existing treatments. Consequently, the following key draws heavily on information from the various papers cited.

1. Lemma awns straight or only slightly curved at maturity

2. Longest lemma awns $17-60 \mathrm{~mm}$ long, at least $3 \times$ the length of the lemmas; hairs of first rachilla segment sometimes overlapping the base of the subtended callus

3. Hairs of first rachilla segment overlapping base of the callus above; calluses not hairy across the back, sometimes hairy on the sides

A. rectiseta

3. Hairs of first rachilla segment not overlapping base of the callus above; calluses hairy across the back

A. longiseta

2. Longest lemmas unawned or the awns shorter than $17 \mathrm{~mm}$, always less than $2.5 \times$ the length of the lemma; hairs of first rachilla segment never overlapping the base of the subtended callus

4. Awn of lowest lemma in each spikelet 2-7.5 mm long, others $4.4-15 \mathrm{~mm}$ long, $70-130 \%$ the length of the lemmas A. fertilis

4. Awn of lowest lemma in each spikelet $0-3 \mathrm{~mm}$ long, others $0-17 \mathrm{~mm}$ long, $0-80 \%$ the length of the lemmas

5. Longest awn in each spikelet shorter than or equal to the lemma body

A. multiflora var. multiflora

5'. Longest awn in each spikelet longer than the lemma body

A. multiflora var. kingiana

1. Lemma awns strongly curved to recurved, at maturity 6

6. Lower glumes 7-11 mm long, 5-8-veined; upper glume narrowing from above midlength, acute; lemma awns sometimes 1-veined at the base A. plurinervis

6. Lower glumes 1.8-11 mm long, 2-4(5)-veined; upper glume tapering from below midlength, acute to shortly $(3 \mathrm{~mm})$ awned; lemma awns 3 -veined at the base .

7. Palea tips truncate to retuse; culms $55-150 \mathrm{~cm}$ long at maturity

8. Hairs at the tip of the first rachilla segment not overlapping the base of the callus above; callus thicker at the tip than above.

8. Hairs at the tip of the first rachilla segment overlapping the base of the callus above; callus similar in thickness throughout its length......

A. rectiseta

7'. Palea tips pointed, bifid; culms $10-100 \mathrm{~cm}$ long at maturity

9. Spikes erect; spikelets divergent; anthers $4-9 \mathrm{~mm}$ long. 
9. Spikes ascending or nodding; spikelets appressed to the rachis; anthers $2.4-5.5 \mathrm{~mm}$ long. 10

10 Leaf blades $1.5-4 \mathrm{~mm}$ wide, flat or with involute margins; auricles $1-1.5 \mathrm{~mm}$ long A. solandri

10'. Leaf blades $0.5-0.7 \mathrm{~mm}$ in diameter, involute; auricles absent or to $1 \mathrm{~mm}$ long.

11. Leaf blades 5-15 cm long; abaxial surface usually with scattered to abundant stiff, erect hairs about $1 \mathrm{~mm}$ long; culms prostrate to ascending A. falcis

11'. Leaf blades $10-80 \mathrm{~cm}$ long; abaxial surface glabrous

A. sacandros

Anthosachne aprica (Á.Löve \& Connor) C.Yen \& J.L.Yang, Xiao mai zu sheng wu xi tong xue 3: 232 (2006). Basionym: Elymus apricus Á.Löve \& Connor, New Zealand J. Bot. 20: 182 (1982). Type: New Zealand, Central Otago, Hillsides above Roxburgh town, H.E. Connor s.n., 10 Feb 1947 (holotype: CHR370822).

NEW ZEALAND: South Island, inland basins of Central Otago.

Anthosachne falcis (Connor) Barkworth \& S.W.L.Jacobs comb. nov. Basionym: Elymus falcis Connor, New Zealand J. Bot. 32: 132 (1994). Type: New Zealand, Canterbury, Mt Edwards, c. 4000 ft, V.D. Zotov s.n., 5 Jan 1938 (holotype: CHR19687).

NEW ZEALAND: South Island, inland Waimakariri, Ashburton, Waitaki, and Taieri Basins.

Anthosachne fertilis (S.Wang ex S.W.L.Jacobs \& Barkworth) Barkworth \& S.W.L.Jacobs comb. nov. Basionym: Elymus fertilis S.Wang ex S.W.L.Jacobs \& Barkworth, Novon 19: 168 (2009). Type: Australia, New South Wales, urban area, Moree 29²8'S, $149^{\circ} 51$ 'E, N. Lloyd 759, 13 Oct 1988 (holotype: NSW220373!)

AUSTRALIA: southern Queensland, New South Wales.

Anthosachne longiseta (Hitchc.) Barkworth \& S.W.L.Jacobs comb. nov. Basionym: Brachypodium longisetum Hitchc., Brittonia 2: 107 (1936). Elymus longiseta (Hitchc.) Veldkamp, Blumea 34: 74 (1989); Roegneria longiseta (Hitchc.) B.R.Baum, C.Yen \& J.L.Yang, Canad. J. Bot. 69: 290 (1991). Type: Papua New Guinea: Central Province, Mt Albert Edward, on grassy banks of Upper Chirima River, 3600 m, L.J. Brass 4446, May-July, 1933 (holotype: NY346160, image!; isotypes: BRI, LAE).

PAPUA NEW GUINEA: Central Province.

Anthosachne multiflora (Banks \& Sol. ex Hook.f.) C.Yen \& J.L.Yang, Xiao mai zu sheng wu xi tong xue 3: 232 (2006). Basionym: Triticum multiflorum Banks \& Sol. ex Hook.f., Fl. Nov.-Zel. 1: 311 (1853). Nomenclatural synonyms: Agropyron multiflorum (Banks \& Sol. ex Hook.f.) Kirk ex Cheeseman, Man. New Zealand Fl. 921 (1906), nom. illeg., non Agropyron multiflorum P.Beauv. (1812); Elymus multiflorus (Banks \& Sol. ex Hook.f.) Á.Löve \& Connor, New Zealand J. Bot. 20:183 (1982).Type: New Zealand, Mercury Bay; J. Banks \& D. Solander s.n., 1769 (lectotype (Connor 1994): $\mathrm{BM})$.

Anthosachne multiflora (Banks \& Sol. ex Hook.f.) C.Yen \& J.L.Yang subsp. multiflora. Nomenclatural synonym: Anthosachne multiflora (Banks \& Sol. ex Hook.f.) C.Yen \& J.L.Yang var. multiflora. 
Taxonomic synonyms: Agropyron multiflorum var. longisetum Hack., Man. New Zealand Fl. 922 (1906); Agropyron kirkii var. longisetum (Hack.) Zotov, Trans. \& Proc. New Zealand Inst. 73: 233 (1943); Elymus multiflorus var. longisetus (Hack.) Á.Löve \& Connor, New Zealand J. Bot. 20: 183 (1983). Type: New Zealand, Matamata, Thames Valley, Cheeseman 1506 (holotype: W; isotypes: AK2017, CHR2877).

AUSTRALIA: South Australia, Victoria, Tasmania, New South Wales.

NEW ZEALAND: North and South Island.

Anthosachne multiflora subsp. kingiana (Endl.) Barkworth \& S.W.L.Jacobs, comb. nov. Basionym: Triticum kingianum Endl., Prod. Fl. Norf. 21 (1833). Festuca kingiana (Endl.) Steud., Syn. Pl. Glumac. 1: 316 (1854); Agropyron kingianum (Endl.) Petrie, Trans. \& Proc. New Zealand Inst. 47: 18 (1915); Elymus kingianus (Endl.) Á.Löve, Feddes Repert. 95: 469 (1984); Elymus multiflorus var. kingianus (Endl.) Connor, Kew Bull. 45: 680 (1990); Elymus multiflorus subsp. kingianus (Endl.) de Lange \& R.O.Gardner, New Zealand J. Bot. 43:571 (2005). Type: Norfolk Island, F.L. Bauer s.n., without date (holotype: W6210, image!) AUSTRALIA: Norfolk Island.

Anthosachne plurinervis (Vickery) Barkworth \& S.W.L.Jacobs comb. nov. Basionym: Agropyron scabrum var. plurinervis Vickery, Contr. New South Wales Natl. Herb. 1: 342 (1951). Nomenclatural synonyms: Elymus scaber var. plurinervis (Vickery) B.K.Simon, Austrobaileya 2: 242 (1986); Elymus plurinervis (Vickery) Connor, New Zealand J. Bot. 43(2): 500 (2005); Anthosachne australasica var. plurinervis (as 'plurinervisa') C.Yen \& J.L.Yang, Xiao mai zu sheng wu xi tong xue 3: 230 (2006). Type: Australia, New South Wales, Inverell, E.O. Thomas 6, Nov 1912 (holotype: NSW8246).

AUSTRALIA: Western Australia, South Australia, Victoria, New South Wales.

Anthosachne rectiseta (Nees) Barkworth \& S.W.L.Jacobs comb. nov. Basionym: Vulpia rectiseta Nees in Lehm., Pl. Preiss. ii: 107 (1846). Nomenclatural synonyms: Festuca rectiseta (Nees in Lehm.) Walp., Ann. Bot. Syst. (Walpers) 1:943 (1849); Elymus rectisetus (Nees) Á.Löve \& Connor, New Zealand J. Bot. 20: 183 (1982). Type: Australia, Western Australia, Herb. Preiss 1819 (holotype: MEL).

Taxonomic synonyms: Anthosachne australasica Steud., Syn. Pl. Glumac. 1: 237 (1854); Elymus australasica (Steud.) Tsvelev, Novosti Sist. Vyssh. Rast. Moscow \& Leningrad [St. Petersburg] 10: 25 (1973); Anthosachne australasica var. typica (Steud.) C.Yen \& J.L.Yang, nom. inval.. , in Yen et al (2006) Xiao mai zu sheng wu xi tong xue 3: 228-229, f. 5-16. Type: Western Australia: Nov. Holl. J. Drummond $4^{\text {th }}$ coll.: 382, 383, 384 (syntypes: K).

AUSTRALIA: Western Australia, South Australia, Victoria, New South Wales.

Anthosachne sacandros (Connor) Barkworth \& S.W.L.Jacobs comb. nov. Basionym: Elymus sacandros Connor, New Zealand J. Bot. 32:138 (1994). Type: New Zealand: Isolation Creek, NW of Ben Moore, Marlborough, 800 ft, A.P. Druce s.n., Dec 1975 (holotype: CHR279320).

Anthosachne scabra (R.Br.) Nevski, Trudy Sredne-Aziatsk. Gosud. Univ., Ser. 8b, Bot. 17: 65 (1934). Basionym: Triticum scabrum R.Br., Prodr. Fl. Nov. Holland.178 (1810). Nomenclatural synonyms: Festuca scabra Labill. (1805), nom . illeg. non Festuca scabra Vahl (1791), Agropyron scabrum (R.Br.) P.Beauv., Ess. Agrostogr. 102 
(1812); Vulpia scabra (R.Br.) Nees, London J. Bot. 2: 419 (1843); Vulpia brauniana Nees, London J. Bot. 2: 419 (1843), nom. superfl. pro V. scabra; Festuca brauniana (as Browniana) (Nees) Walp., Ann. Bot. Syst. (Walpers) 1:943 (1849); Festuca billardierei (as Billardieri) Steud., Syn. Pl. Glumac. 1:304 (1854); Elymus scaber (R.Br.) Á.Löve, Feddes Repert. 95(7-8): 468 (1984); Roegneria scabra (R.Br.) J.L.Yang \& C.Yen, Canad. J. Bot. 69: 291 (1990); Anthosachne australasica var. scabra (R.Br.) C.Yen \& J.L.Yang, Xiao mai zu sheng wu xi tong xue 3: 228 (2006). Type: Australia, Tasmania: in capite Van-Diemen [Hobart], J.J.H. de Labillardiere s.n., 1793 (holotype: FI).

Anthosachne solandri (Steud.) Barkworth \& S.W.L.Jacobs comb. nov. Basionym: Triticum solandri Steud., Syn. Pl. Glumac. 1: 347 (1854). Triticum squarrosum Hook.f., London J. Bot. 3: 417 (1844), nom. illeg., non Roth (1802). Triticum youngii Hook.f., Handb. New Zealand Fl. 1: 343 (1864); Agropyron youngii (Hook.f.) P.Candargy, Archiv. Biol. Veg., Athenes, Fasc. 1: 39 (1901); Elymus solandri (Steud.) Connor, New Zealand J. Bot. 32: 140 (1994). Type: New Zealand: “in rupibus prope Totarnui" (specimens on left and right) J. Banks \& D. Solander s.n. (lectotype (Connor 1994): BM38288).

\section{Connorochloa Barkworth, S.W.L.Jacobs \& H.Q.Zhang}

Connorochloa Barkworth, S.W.L.Jacobs \& H.Q.Zhang, Breeding Science 59: 685 (2009). Type species: Connorochloa tenuis (Buchanan) Barkworth, S.W.L.Jacobs, \& H.Q.Zhang [三Elymus tenuis (Buchanan) Á.Löve \& Connor].

Plants perennial, stoloniferous. Culms 66-200 cm, internode below the inflorescence (peduncle) elongating greatly after anthesis and lying along the ground; lowest internode $0.5-1 \mathrm{~mm}$ thick. Leaf blades to $1.2-2 \mathrm{~mm}$ wide, flat to somewhat involute. Inflorescence spikelike, $10-15 \mathrm{~cm}$ long, with 5-15 nodes; lowest internode $18-28 \mathrm{~mm}$ long; middle internodes $12-20 \mathrm{~mm}$ long; rachis prolonged beyond the base of the distal floret; disarticulation below the florets. Spikelets solitary, tangential to the rachis, 25-40 mm long, with 6-8 florets. Glumes lanceolate, 3-10 mm long, coarsely scabrous, shorter than the adjacent lemmas, 3-veined, tapering into a stiff, scabrous awn up to $5 \mathrm{~mm}$ long. Lemmas 6-10 $\mathrm{mm}$ long, mostly smooth, margins and distal portion of midvein scabrous, tip awned, awns 15-35 mm long. Paleas 7-10 $\mathrm{mm}$ long, tapering to a narrow tip. Anthers 2-3 mm, yellow.

Distribution: only one species is known. It is endemic to New Zealand.

Cytology: $2 n=56$. Genomic constitution StYHW (Zhang et al. 2010).

History: Connorochloa was first recognised as a distinct genus in December, 2009. In describing it, Barkworth et al. (2009) acknowledged that it is morphologically very similar to some species of Anthosachne, differing from them in being octoploid and its combination of basal leaves that are 1-1.5(2) $\mathrm{mm}$ wide, upper glumes that have 1.3-6.5 mm long awns, and straight lemma awns (9)15-35 mm long. It was also thought to be unique in having peduncles that elongate and become prostrate after anthesis but plants identified as Anthosachne scabra in Victoria, Australia, have a similar habit. Clearly, further study is needed.

Connorochloa tenuis (Buchanan) Barkworth, S.W.L.Jacobs, \& H.Q.Zhang, Breeding Science 59: 685 (2009). Basionym: Agropyron scabrum var. tenue Buchanan, Indig. Grasses New Zealand, Add. \& Corr. 11 (1880). Nomenclatural synonyms: Agropyron tenue (Buchanan) Connor, New Zealand J. Sci. Technol. B35: 318 (1954); 


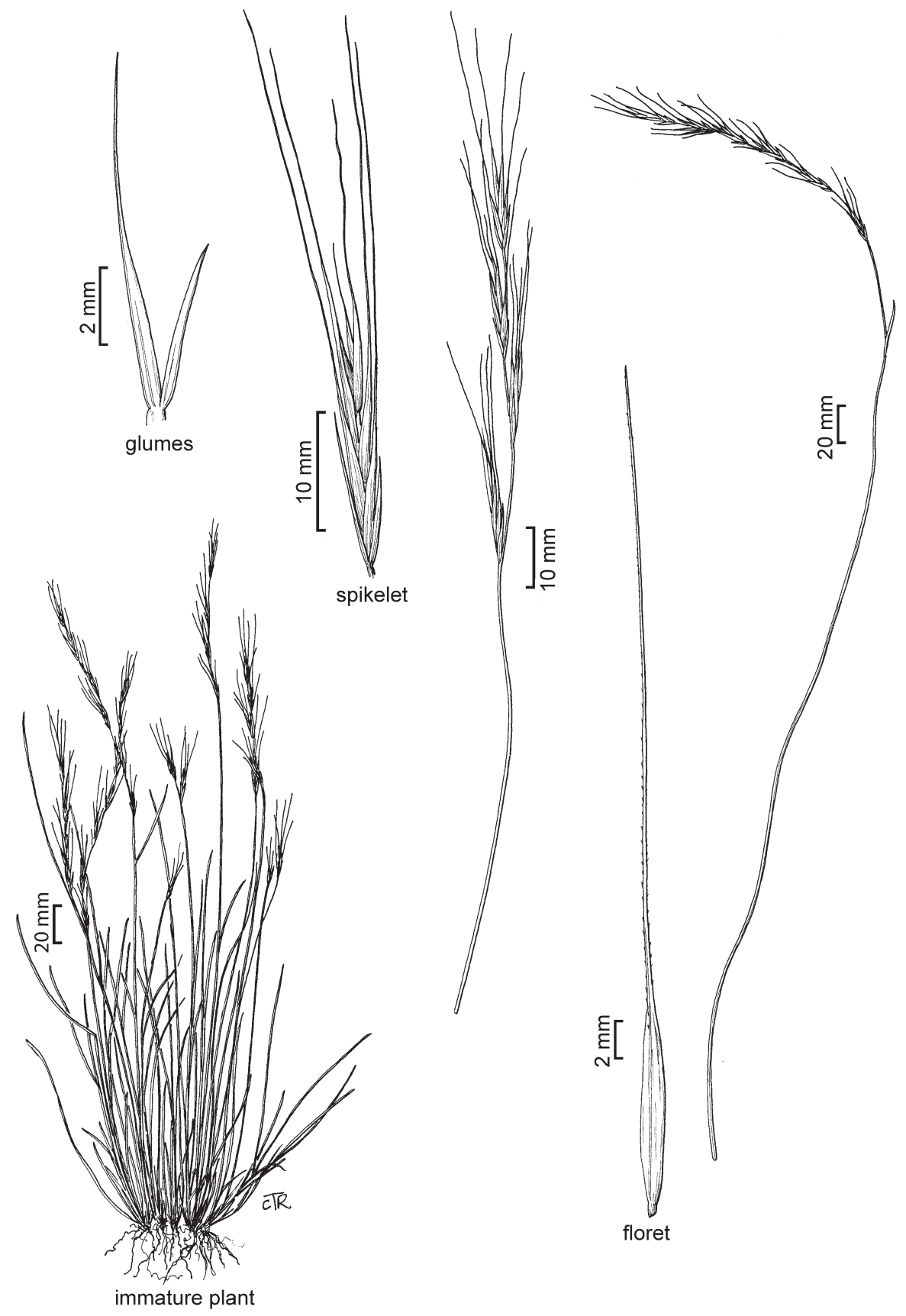

Fig. 4. Connorochloa tenuis: Johnson s.n., 21 Jan 1982, CHR 364502 and Dewey D-2970, 2 Jul 1984, UTC 250464 (immature plant grown from seed sent by Connor). 
Elymus tenuis (Buchanan) Á.Löve \& Connor, New Zealand J. Bot. 20: 183 (1982). Type: New Zealand, without locality or date, Buchanan's folio. (holotype: WELT59620, image!).

\section{Discussion}

The primary purpose of this paper was to publish the names required for adoption of the generic conclusions explained in Barkworth et al. (2009). Almost all the changes involve Australasian taxa currently included in Elymus by botanists in the region, most of which are transferred to Anthosachne. Consequently, recognising it will be easy for people already familiar with the Triticeae in Australasia. Distinguishing Connorochloa from Anthosachne is, admittedly, hard; some will consider its recognition as a genus inappropriate. The discovery of plants, currently included in Anthosachne scabra, that seem to have a similar habit certainly raises questions. We decided to stand by our earlier decision pending further study of Anthosachne.

The situation with respect to Connorochloa emphasises the desirability of completing taxonomic revisions before publishing new names. Unfortunately, completing such a revision will probably take, even with funding, three or more years and several nomenclaturally incorrect names have already been published. It seemed best, therefore, to present names that reflect the species-level treatment of the Australasian taxa by those familiar with them.

\section{Acknowledgments}

I shall be forever grateful for being told, in 1980, that there was an Australian botanist, Surrey Jacobs, working on the Stipeae. We met at the IBC in Sydney. Since that time, I have had the privilege of joining Surrey on many field trips and talking with him on a wide range of subjects, including plants. This paper arose from observations while we were collecting Stipeae in Australia in 2007. It began as a joint publication, and the initial draft was prepared by Surrey. Sadly, soon thereafter he became too ill to work so, for all its flaws, I accept full responsibility.

Surrey would join me in thanking Henry Connor for assisting us by selecting good specimens of the New Zealand taxa for my examination. It should be noted that Connor disagrees with our decision to recognise Connorochloa at the generic level. We also thank the curators of CANB and CHR for the loan of specimens to UTC that made this study possible and Cindy Roché for the line drawings. The manuscript has benefited from the comments of the reviewers, including helpful information concerning Papua New Guinea and collections made there and from the request of the editor, Elizabeth Brown, that I provide information on the location of type specimens. I thank her for the request and Gina Terrell (CBG), Egildo Luccioli (FI), Chiara Nepi (FI), Maria Vorontsova (K), and Robert Vogt (B) plus several TAXACOM respondents who helped me comply with it. Many will join me in thanking Gerrit Davidse for posting the resulting information, including images, to TROPICOS and Kanchi Gandhi for posting the names published by Yen and Yang to IPNI. I also thank Kanchi for answering my nomenclatural questions.

I also thank Neville Walsh and Wal Whalley both of whom took me to see Anthosachne 
in the field in 2009, shared their observations with me, and encouraged further study of the genus and the curators of AD, MEL, NE, and PERTH who have loaned me specimens for this purpose. I am still in the process of studying them.

Mary E. Barkworth

\section{References}

Barkworth ME, Cutler DR, Rollo JS, Jacobs SWL \& Rashid A (2009) Morphological identification of genomic genera in the Triticeae. Breeding Science 59: 561-570.

Baum BR, Estes JR \& Gupta PK (1987) Assessment of the genomic system of classification in the Triticeae. American Journal of Botany 74: 1388-1395.

Baum BR, Yang JL \& Yen C (1995) Taxonomic separation of Kengyilia (Poaceae: Triticeae) in relation to nearest related Roegneria, Elymus, and Agropyron, based on some morphological characters. Plant Systematics and Evolution 194: 123-132.

CBIT (2005) Fact Sheet Fusion, a program for creating standardized fact sheets. (Centre for Biological Information Technology, University of Queensland, Brisbane, Australia)

CBIT (2004) Lucid Phoenix, a program for providing interactive dichotomous keys. (Centre for Biological Information Technology, University of Queensland, Brisbane, Australia)

CBIT (2009) Lucid 3.5, a program for creating interactive multi-access keys. (Centre for Biological Information Technology, University of Queensland, Brisbane, Australia)

Connor HE (1954) Studies in New Zealand Agropyron, parts 1 and 2. New Zealand Journal of Science and Technology B 35:315-342.

Connor HE (1994) Indigenous New Zealand Triticeae: Gramineae. New Zealand Journal of Botany 32:125-154.

Connor HE (2005) Flora of New Zealand - Gramineae supplement II: Pooideae (Poeae, Triticeae). New Zealand Journal of Botany 43: 493-508.

Connor HE, Molloy BPJ \& Dawson MI (1993) Australopyrum (Triticeae: Gramineae) in New Zealand. New Zealand Journal of Botany 31:1-10.

Cutler DR, Edwards Jr. TC, Beard KH, Cutler A, Hess KT, Gibson J \& Lawler JJ (2007) Random Forests for classification in ecology. Ecology 88: 2783-2792.

Dawson MI (2000) Index of chromosome numbers of indigenous New Zealand spermatophytes. New Zealand Journal of Botany 38: 47-150.

Dewey DR (1984) The genomic system of classification as a guide to intergeneric hybridization with the perennial Triticeae. Pp. 209-279 in Gustafson JP (ed) Gene manipulation in plant improvement. (Plenum Press: New York)

Edgar E \& Connor HE (2000) Flora of New Zealand, vol. 5. Gramineae. (Manaaki Whenua Press: Lincoln, New Zealand)

Flora of Australia (2009) Vol. 44a, Poaceae 2. (ABRS, Canberra/CSIRO Publishing, Melbourne)

Hair JB (1956) Subsexual reproduction in Agropyron. Heredity 10: 129-160.

Henwood MJ \& Weiller (2009) Australopyrum. Pp. 107-110 in Flora of Australia (2009) vol. 44a, Poaceae 2. (ABRS, Canberra/CSIRO Publishing, Melbourne)

Hitchcock AS (1936) Botanical results of the Archbold expedition No. 1 Papuan grasses collected by L.J. Brass. Brittonia 2: 107-130.

Jacobs SWL, Whalley RDB \& Wheeler DJB (2008) Grasses of New South Wales, edition 4. (University of New England, Armidale, New South Wales, Australia)

Kellogg EA (1989) Comments on genomic genera in the Triticeae (Poaceae). American Journal of Botany 76: 796-805.

Liu Ql, Ge S, Tang Hb, Zhang Xl, Zhu Xl, Zhu Gf, \& Lu B-R (2006) Phylogenetic relationships in Elymus (Poaceae: Triticeae) based on the nuclear ribosomal internal transcribed spacer and chloroplast trnL-F sequences. New Phytologist 170: 411-420. 
Liu Zp, Chen Sy, Pan j, Li Xf, Su M, Wang Xf, Li Xf \& Liu Gs (2008) Phylogenetic relationships in Leymus (Poaceae: Triticeae) revealed by the nuclear ribosomal internal transcribed spacer and chloroplast trnL-F sequences. Molecular Phylogenetics and Evolution 46: 278-289.

Löve Á (1984) Conspectus of the Triticeae. Feddes Repertorium 95:1-521.

Löve Á \& Connor HE (1982) Relationships and taxonomy of New Zealand Wheatgrasses New Zealand Journal of Botany 20: 169-186.

Löve Á, McGuire P \& Pullen R (1982) Australopyrum velutinum P. 126 in Löve Á (ed.) IOPB chromosome number reports LXXIV. Taxon 31: 126.

Melderis A (1970) Agropyron. Pp. 150-184 in Bor NL. Gramineae in Rechinger KH (ed.) Flora Iranica 70 (Akaemische Druck-u Verlagsanstalt, Graz, Austria)

Murphy MA (2003) Relationships among taxa of Elymus (Poaceae: Triticeae) in Australia: reproductive biology. Australian Systematic Botany 16: 633-642.

Murphy MA, Jones CE (1999) Observations on the genus Elymus (Poaceae: Triticeae) in Australia. Australian Systematic Botany 12: 593-604.

Murray BG, Lange PJ de, Ferguson, AR (2005) Nuclear DNA variation, chromosomes numbers, and polyploidy in the endemic and indigenous grass flora of New Zealand. Annals of Botany 96: 1293-1305.

Nevski SA (1934) Anthosachne. Pp. 597-598 in Roshevitz RY \& Shishkin BK (eds) Flora URSS in translation by Landau, NR (1963) (Israel Program for Scientific Translations, Jerusalem, Israel)

Redinbaugh MG, Jones TA \& Zhang Y (2000) Ubiquity of the St chloroplast genome in Stcontaining Triticeae polyploids. Genome 43: 846-852 .

Salomon B \& Lu B-R (1992) Genomic groups, morphology, and sectional delimitation in Eurasian Elymus (Poaceae: Triticeae). Plant Systematics and Evolution 180:1-13.

Seberg O \& Petersen G (1998) A critical review of concepts and methods used in classical genome analysis. The Botanical Review 64: 4-417.

Simon BK (1986) Studies in Australian grasses 2. Austrobaileya 2: 238-242

Steudel EG von (1854 [1855]) Synopsis plantarum Glumacearum, vol. 1, part 1. (J.B. Metzler, Stuttgart)

Stewart AV, Ellison N, Salomon B, \& Connor HE (2005) Genomic constitution of New Zealand Triticeae. Czech Journal of Genetics and Plant Breeding 41 (Special Issue): 98-100.

Svitashev S, Byrngelsson T, Li X \& Wang RRC (1998) Genome-specific repetitive DNA and RAPD markers for genome identification in Elymus and Hordelymus. Genome 41: 120-128.

Torabinejad J, Carman JG, \& Crane CF (1987) Morphology and genome analyses of interspecific hybrids of Elymus scabrus. Genome 29: 150-155.

Torabinejad J \& Mueller RJ (1993) Genome constitution of the Australasian hexaploid grass Elymus scabrus (Poaceae: Triticeae). Genome 36: 147-151.

Tsvelev NN (1973) Conspectus specierum tribus Triticeae Dum. familiae Poaceae in flora URSS. Novosti sistematik vysshikh rastenii Moscow 10: 19-59.

Tsvelev NN (1976) Grasses of the Soviet Union. Part 1. Translated for the Smithsonian Institution 1983. (Oxonian Press, New Delhi)

Turczaninow NS (1862) Decas generum plantarum. Bulletin de les Socialistes des Naturalistes. Moscow, Decas 8: 35.

Veldkamp JF \& Scheindelen van HJ (1989) Australopyrum, Brachypodium and Elymus (Gramineae) in Malesia. Blumea 34: 61-76.

Wheeler DJB, Jacobs SWL \& Norton BE (1990) Grasses of New South Wales, edition 2. (University of New England Monographs, Armidale, New South Wales)

Wheeler DJB, Jacobs SWL \& Whalley RDB (2002) Grasses of New South Wales, edition 3. (University of New England Monographs, Armidale, New South Wales) 